\title{
A TRANSVERSALIDADE DA EDUCAÇÃO AMBIENTAL NA PRÁTICA
}

Cristiano Trindade De Angelis ${ }^{1}$

Vinicius Ferreira Baptista ${ }^{2}$

Resumo: De acordo com o economista e filósofo indiano Amartya Sen uma das liberdades mais importantes é a da participação e controle social, o que pode ser um instrumento na proposta de um novo paradigma na Educação Ambiental para melhora da efetividade dos programas e projetos públicos nesta área. Isso depende da formação de um cidadão culto e ecológico, através da mudança de atitudes, derivada da Educação Ambiental das crianças nas escolas e dos cidadãos através de campanhas de incentivo à leitura e de conscientização ecológica dos adultos. 0 estudo conclui que a transversalidade na temática ambiental, inicialmente nas escolas de Mariana e Brumadinho, e as campanhas de conscientização da população incentivam a participação e controle social de qualidade e tem o potencial de criar um novo paradigma na Educação Ambiental.

Palavras-chave: Acesso ao Conhecimento; Educação Ambiental; Liberdade; Participação Popular.

Abstract: One of the most important freedoms is that of participation and social control in government action, which can be an instrument in the proposal of a new paradigm in environmental education to improve the effectiveness of public programs and projects in this area. This depends on the formation of a cultured and ecological citizen, through the change of attitudes, derived from the environmental education of children in schools and citizens through campaigns to encourage reading and ecological awareness of adults. Formal and informal Environmental Education must become a process that sows the fermentation of the formation of a new culture, through a new form of thinking. Offering a new perspective for existing literature, and based on the approach to development as freedom, this article presents a theoretical-practical model of environmental education based on Communities of Practice, which can be applied, with contributions of future research, in an environmental education policy in Brazil. This model demonstrates that access to knowledge and experience leads to the character formation of an ecological citizen and then to social control and social participation. The study concludes that the pilot project, with the insertion of the discipline of environmental education in the schools of Mariana and Brumadinho, where the two mud tsunamis occurred, and the awareness campaigns of the population enhance participation and social quality control and have the potential to create a new paradigm in Environmental Education.

Keywords: Access to Knowledge; Environmental Education; Freedom; Social Participation.

\footnotetext{
${ }^{1}$ Ministério da Economia e Skema Business School. E-mail: cristiano.deangelis@skema.edu, Link para o Lattes: http://lattes.cnpq.br/6131315973253089

2Universidade Federal Rural do Rio de Janeiro. E-mail: viniciusferbap@ufrrj.br.

Link para o Lattes: http://lattes.cnpq.br/1519850039767968
}

Revbea, São Paulo, V. 15, № 5: 440-463, 2020. 


\section{Introdução}

Em 2015 e 2019 registaram-se os rompimentos nas barragens do Fundão, Mariana, e do Complexo do Feijão, Brumadinho, ambos localizados no Estado de Minas Gerais, no Brasil. Mais de 2.000 hectares de solos foram destruídos com mais de 330 mortes e muitos desaparecidos. Em busca de uma solução para o desemprego em ambas as regiões, precisamos de compreender a zona rural não só como espaço de biodiversidade e preservação da vida natural, o ecológico - ambiental, mas também da função de fornecer alimentos, fibras e matérias-primas, agricultura, e também como vocação turística, o turismo rural ainda incipiente. Mas primeiro temos de compreender a importância da Educação Ambiental para a biodiversidade e a sustentabilidade.

A Educação Ambiental formal para crianças é o mais importante do ponto de vista curricular e pedagógico na formação intelectual das mesmas e deve-se ter uma atenção especial não apenas aos conteúdos, mas aos processos autônomos que considerem a totalidade das relações sociais e não uma Educação mecânica e instrumental de acúmulo de conteúdo de uma formação bancária (FREIRE, 1994). Mesmo que as crianças não tenham capacidade de discernimento e decisão racional na medida comparativa aos adultos, é na fase infantil que são formados as crenças, valores e suposições que orientação seus comportamentos, expectativas e interpretações de mundo.

A proposta de Educação Ambiental para crianças está baseada no modelo proposto pelo o Instituto Ciclos do Brasil - uma ONG criada em 2008 no Rio de Janeiro. O Instituto Ciclos do Brasil criou os projetos Livro de Rua e Tabernados Bardos que recebem apoio financeiro através de pequenos e médios empresários do próprio Bairro onde está a escola, visto que o projeto tem tratado o caráter de crianças e adolescentes, com diminuição significativa da violência. Após a entrega dos livros são realizadas oficinas de contação de histórias com ajuda de professores e psicopedagogas. Há de se destacar, contudo, a dificuldade dos professores com o tema de Educação Ambiental, que é o principal obstáculo na inserção do tema Educação Ambiental, de forma transversal, nas Escolas de Mariana e Brumadinho como projeto piloto.

Em relação aos jovens e adultos o modelo proposto sugere campanhas governamentais de conscientização ecológica com doação de livros e orientação. Tanto a educação formal como a informal ajudam na formação de um cidadão culto e ecológico que tem potencial de contribuir tanto no controle como na participação social o que leva a construção e execução de políticas públicas e privadas mais efetivas, isto é, com melhores resultados do ponto de vista dos beneficiários.

Este artigo estrutura-se como segue. Além desta introdução e das conclusões, a seção 1 discute as relações teóricas entre o desenvolvimento como liberdade, educação e cidadania. A seção 2 mostra as dificuldades e mudanças propostas tanto na educação formal como na informal. A seção 3 adentra ao tema da participação e controle social e então defende o modelo do

revista brasileira educação ambiental 
Novo Serviço Público (NSP), finalmente, a seção 4 expõe o modelo EFIGE, combinando os diversos elementos teóricos colhidos ao longo das seções anteriores.

\section{A relação entre desenvolvimento como liberdade, educação e cidadania}

A visão de Amartya Sen (2010) sobre o desenvolvimento é chamada de "abordagem do desenvolvimento como liberdade" ou "abordagem das capacitações". Para este autor indiano, o desenvolvimento está vinculado ao alargamento das capacidades e liberdades humanas, em um processo no qual se ampliam as escolhas pessoais para viver de forma plena a vida. Isso implica que a boa ação pública não somente distribui bens a recipientes passivos, mas também amplia as escolhas das pessoas e promove suas capacidades, incluindo a capacidade de escolha.

Andrade et al. (2016) sustentam que o crescimento econômico precisa acompanhar-se de instrumentos que possibilitem o avanço das capacidades para a população, por meio de ferramentas distributivas.

Por sua vez, a educação permite que o indivíduo amplie os seus horizontes cognitivos, tenha acesso a informações importantes, conhecimentos e saber, compreenda melhor o mundo e a si próprio e se posicione diante dos problemas da vida mais aparelhado para resolvê-los. Segundo Sen (2000), a educação figura como uma liberdade instrumental para o desenvolvimento. Tão importante é a educação que se pode dizer que ser bem-educado é um fim em si mesmo, dada a indissociabilidade prática entre o ser bem educado e o ser livre. Daí porque a privação da liberdade educacional é tão grave para o desenvolvimento de um povo, merecendo os maiores e melhores esforços da sociedade para sanar essa privação.

No caso das privações educacionais do povo brasileiro, em tese é fácil mostrar que elas interagem com a baixa produtividade do trabalho, com os baixos rendimentos do trabalhador, o que deve ser um obstáculo tanto a um crescimento mais vigoroso da renda per capita no longo prazo, quanto na consecução de um perfil de renda mais equitativo no Brasil. Caberá a trabalhos empíricos mostrar a existência e magnitude do efeito da falta de educação do brasileiro sobre a falta de consciência ecológica, que, conquanto esteja presente há séculos em nosso país, após os tsunamis de lama ocorridos em Brumadinho e Mariana têm tido grande impacto na vida social e política nacional. Contudo, do ponto de vista teórico, é possível mostrar que a liberdade política, tão duramente conquistada no Brasil, só vai dar bons resultados quanto a educação e consciência ecológica, quando houver acesso geral à educação de qualidade e liberdade de expressão nos diálogos entre governo e sociedade.

Um sistema educacional de qualidade e equilibrado em seus segmentos científico e humanístico é fundamental na promoção da condição de agente, de que fala Sen (2000): é fundamental que as pessoas tenham o poder 
de agir como cidadãos, não se restringindo a meros vassalos bem alimentados, bem vestidos e bem entretidos. Um Estado que tome todas as decisões em nome do cidadão, ao não Ihe deixar qualquer opção de escolha, também limita a responsabilidade pessoal. Ora esse estado de coisas seria um gritante obstáculo ao desenvolvimento como liberdade. Uma alternativa razoável é a defesa de um Estado que forneça mais oportunidades de escolha às pessoas, para que elas exercitem a sua responsabilidade (idem, ibidem, p. 284). Portanto, a abordagem do desenvolvimento como liberdade, de Amartya Sen, pode articular coerentemente os temas da educação, cidadania e educação/conscientização ambiental.

Não há, contudo, nenhuma medida para efetivação, de forma transversal, do tema de Educação Ambiental nas escolas, apesar do que rege a Política Nacional de Educação Ambiental (PNEA), regida pela Lei n`9795/99, e a resolução $n^{\circ} 02 / 2012$ do Conselho Nacional de Educação. Apesar do Art. 4은 da Lei $n^{\circ} 9795 / 99$ (BRASIL, 1999) indicar a transdisciplinaridade em seu inciso III como Princípio, trabalhar conteúdos pelas lógicas fechadas de "disciplinas", ou agregá-las em um ecletismo disciplinar não é o mesmo que construir processos pedagógicos que sejam transversais. No mesmo processo vemos a expressão de um princípio "holístico" de enfoque no inciso I, mas não devidamente indicado em que ponto. Ainda assim, podemos ver um esforço normativo na construção política, ainda que não tenhamos revisão da lei acerca deste ponto.

Portanto o desenvolvimento da cidadania no Brasil é mais uma questão de prática do que de teoria; mais de arte do que de ciência. Acima de tudo, trata-se de um longo processo histórico de desempoderamento das massas. Para mudar isso é preciso desenvolver as capacidades "senianas" dos indivíduos - com destaque para suas liberdades instrumentais (econômicas, sociais, políticas, transparência e seguridade) -, quanto os arranjos institucionais que canalizam a vontade popular para a ação do poder público.

Este artigo defende que o desenvolvimento da cidadania, como um processo de amadurecimento democrático popular coetâneo ao desenvolvimento das capacitações do povo e à consolidação de mecanismos institucionais efetivos de governança, é uma condição necessária, mas não suficiente para educação e consciência ambiental. Antes, porém, de apresentar o modelo que procura estabelecer essas relações, é preciso passar em revista à literatura sobre o assunto. Isto será feito na seção a seguir.

\section{Soluções para Educação Ambiental formal (tema transversal às disciplinas obrigatórias) e informal (campanhas do governo, empresas e instituições de ensino)}

No livro Educação Ambiental na Educação Básica: entre a disciplinarização e a transversalidade da temática socioambiental (LAMINGUEDES; MONTEIRO, 2017) há uma coletânea de artigos que fazem críticas 
construtivas ao Projeto de Lei do Senado 221/2015, o qual alterou a Lei 9795/99.

Todos demonstram de forma inequívoca que a transversalidade é mais adequada que a disciplinarização da Educação Ambiental (LAMIN-GUEDES; MONTEIRO; ALVES; GRANDISOLI; NETO; DE CAMARGO; MUNIZ e LACERDA; COSTA; FREITAS; BORGES; FERREIRA; MERELLES, 2017)

A proposta do PL 221/2015 é dissonante das orientações até então vigentes, e até mesmo dos Parâmetros Curriculares Nacionais, que tratam a temática ambiental no formato de tema transversal às disciplinas obrigatórias (NETO; KAWASAKI, 2015).

Neto (2017) destaca que a Política Nacional de Educação Ambiental prevê que a Educação Ambiental deve ser trabalhada nas escolas por meio de propostas integradas interdisciplinares, e não de maneira disciplinar. A criação de disciplinas específicas para a Educação Ambiental é vislumbrada apenas em cursos de formação de professores, como em licenciaturas ou cursos de especialização.

Dentre todos os artigos que compõe o livro (LAMIN-GUEDES; MONTEIRO, 2017), o que toca de forma mais direta na questão crucial, o exercício da cidadania a partir da interdisciplinariedade do currículo para educar ambientalmente os estudantes brasileiros, é o artigo "Educação Ambiental no Ensino Formal" (DE BARROS, 2017).

Em linhas gerais DE BARROS (2017) aponta que para uma transformação efetiva é necessária uma Educação Ambiental crítica, participativa, dialógica e ética em todas as modalidades e em todos os níveis. Portanto esta educação demanda, fundamentalmente, a formação inicial e continuada de educadores, sob perspectiva global e interdisciplinar.

A autora salienta que atuar no campo ambiental, exige leituras globalrelacionais do mundo para uma apreensão conjuntiva da realidade, e isso envolve repensar e avaliar os objetivos dos programas curriculares dos educadores de hoje-para-amanhã, nos diversos âmbitos e níveis do conhecimento e, pois, do ensino. Tal perspectiva também é prevista na Lei 9,795/1999 (BRASIL, 1999). Tentar transformar a Educação Ambiental em uma disciplina é fugir da responsabilidade de assumir medidas que viabilize o que foi assumido como compromisso e instituído em documentos legais. Se o sistema educacional não consegue se adequar a uma lei que foi construída e elaborada a partir de discussões tão sólidas é preciso avaliar o que a impede de acontecer e buscar solucionar estes obstáculos que trancam a construção de uma sociedade ética e civilizada (DE BARROS, 2017).

Para sustentar sua opinião DE BARROS (2017) aborda um trabalho de Carneiro (2006) ao explicar que essa visão de mundo contraria a concepção reducionista de que a natureza é uma simples fonte de recursos que existe para atender a um progresso hegemônico de produção e consumo regulado 
por leis que interpretam pragmaticamente a solução par estes problemas (CARNEIRO, 2006).

De Barros (2017) também destaca a carta de Belgrado (1975; Unesco, 2016), onde está registrado, há 45 anos atrás, uma necessidade de rever valores e interesses políticos -econômicos - sociais.

Assim também se posiciona Macedo (1999), ao apontar a dificuldade da efetivação da transversalidade pelos $\mathrm{PCNs}$, devido à hegemonia da disciplinarização, fortalecida pelo capitalismo (FERREIRA; MEIRELES DE SÁ, 2007).

Por questão ambiental, Toynbee a entende como "a contradição fundamental que se estabeleceu entre os modelos de desenvolvimento adotados pelo homem marcadamente a partir do século XVIII, e a sustentação deste desenvolvimento pela natureza". O autor, particularmente, refere-se aos modelos de cunho capitalista de desenvolvimento, que não levam em consideração as bases de recursos existentes no planeta. Ao mesmo tempo, por contextos ampliados para além de questões "ambientais", mas relacionados à conjuntura social, política e econômica atrelada à vida das pessoas em ambiente equilibrado e saudável (BAPTISTA, 2012).

Na prática das escolas, importante a pesquisa de Pipitone e Nossllala (2010) por meio de questionários e entrevistas em três escolas estaduais paulistas de ensino fundamental localizadas no município de Piracicaba, estado de São Paulo. Um dos professores, alertou que os alunos vivem numa realidade permeada totalmente pela tecnologia, então eles não veem a preservação dos recursos naturais como aspecto importante para seu cotidiano. Resultados semelhantes foram encontrados em pesquisa realizada por Tozoni-Reis, Teixeira e Maia (2011). Os professores se aproveitam para não cumprir o que rege a Política Nacional de Educação Ambiental (PNEA), regida pela Lei n`9795/99, e a resolução n02/2012 do Conselho Nacional de Educação que estabeleceu as Diretrizes Curriculares Nacionais para a EA e dispõem sobre a transversalidade da EA em todos os níveis e modalidades de ensino.

Macedo (1999) questiona o porquê dos temas transversais não serem o núcleo central da estruturação curricular, uma vez que expressam temáticas relevantes para a formação cidadã dos alunos. Neste ponto, Freire (1994) destaca como uma das maiores dificuldades de processos educacionais transversais é sua compreensão ampliada da Pedagogia e seu afastamento dos processos de aprendizados compartimentalizados, fechados em disciplinas ou em componentes curriculares restritos à conteúdos disciplinares.

Voltamos aqui ao ponto central deste artigo: a educação como liberdade do economista e filósofo indiano Armatya Sen (2000).

A participação e o controle social são os principais elementos de uma governança compartilhada entre Estado e sociedade a fim de melhorar a efetividade das políticas públicas a partir da contribuição de um cidadão culto, 
ético e ecológico. A governança compartilhada gera conhecimento relevante e sabedoria se há interesse do Estado em organizar, transferir e utilizar essa contribuição. O conhecimento popular tem o potencial de mudar os valores, crenças e suposições dos atores públicos, em especial, quando somado ao aprendizado das escolas e universidades.

Borges (2017) em seu artigo "Educação Ambiental: menos discursos para dar tempo a mais ações" destaca a necessidade de práticas de reutilização, reciclagem, reúso de produtos e matérias primas e o consumo consciente' que já estão inseridas na legislação vigente de Educação Ambiental mas que não são raramente cumpridas.

Pipitone e Nossllala (2010) em entrevistas com professores meio de questionários e entrevistas, em três escolas estaduais paulistas de ensino fundamental localizadas no município de Piracicaba, estado de São Paulo, encontraram que alguns deles citam diversas vezes a EA como meio para preservar recursos como água, solo, ar, bens necessários a vida humana e ações para melhoria da qualidade de vida do homem como a questão do destino correto do lixo produzido, plantio de árvores em áreas urbanas, economia de energia, etc.

Borges (2017) ressalta que o PL 221/2015 é também redundante e que não há necessidade de mais leis, mas ações para fortalecer uma consciência crítica sobre a problemática ambiental e social (objetivo fundamental III da PNEA), bem como o incentivo à preservação do equilíbrio do meio ambiente, tendo a defesa da qualidade ambiental como um valor inseparável do exercício da cidadania (objetivo fundamental IV da PNEA).

No artigo "De qual mudança a Educação Ambiental precisa?", Ferreira e Meirelles de Sá (2017) criticam a inserção da disciplina de Educação Ambiental no currículo visto não saber quem seria o profissional apto a ministrar as aulas. Como poderia um único profissional dominar assuntos pertinentes a diversos campos do saber, como história, ecologia e urbanismo? Quais seriam os conteúdos conceituais considerados pertencentes a essa "disciplina" e que seriam essenciais para uma interpretação dos problemas socioambientais contemporâneos?.

Para basear sua opinião Ferreira e Meirelle de Sá (2017) buscaram o entendimento de Bursztyn (2004) que defende "a própria natureza e complexidade dos problemas a serem tratados no universo dos temas ambientais - sinergias, objetos mutantes, abrangências, interesses envolvidos, superposição de diferentes escalas, revisão de paradigmas consagrados etc. exige que as competências a serem mobilizadas sejam amplas". E destacam: Infelizmente, "ainda há resistências elou incompreensões sobre a interdisciplinaridade e a transversalidade, que resultam em uma aparente baixa eficácia das ações de Educação Ambiental nos ambientes escolares" (BERNARDES; PIETRO, 2010). 
Aqui parece que a palavra eficácia, utilizada BERNARDES; PIETRO (2010), poderia ser substituída por efetividade.

De acordo com Drucker (1993) os conceitos de eficiência e eficácia devem ser empregados, na maioria dos casos, em conjunto, para que se consiga atingir plenamente os objetivos estipulados (eficácia) e fazer isso com o melhor aproveitamento do tempo e dos recursos (eficiência). A efetividade, por sua vez, diz respeito ao resultado concreto, ou às ações que fizeram acontecer esse resultado concreto (fins - objetivo e metas desejadas) e estabelece a relação entre os resultados e o objetivo. A Efetividade significa conseguir ser eficiente e eficaz ao mesmo tempo, isto é, obter o melhor resultado possível, maximizando os recursos disponíveis, e atingir os objetivos determinados sob o ponto de vista do beneficiário. Uma política efetiva de Educação Ambiental seria efetiva se bem avaliada pelos alunos e com bom resultado na comunidade em que vivem.

Por outro lado, em termos públicos, poderíamos considerar a Efetividade na ótica da responsabilidade pública (em inglês, situaríamos o termo responsiveness) no contexto de como a Educação Ambiental Crítica poderia contribuir à transformação concreta de Cidadania frente à compreensão de problemas públicos de relevância social ao desenvolvimento humano. Neste ponto, a Educação Ambiental, transversalmente construída, pautada por valores humanistas, poderia apontar para sujeitos sociais e políticos concretos que materializem a responsabilidade sobre si e considerando a dimensão da vida coletiva.

Contudo, ainda mais importante nessa discussão é a inserção do contexto cultural (crenças, valores, suposições e tradições) e a observância do forte impacto da cultura nacional na Gestão do Conhecimento da sociedade e na Inteligência Governamental, assuntos levantados por De Angelis (2018, 2016, 2015 e 2013).

Ferreira e Meirelles de Sã (2007) argumentam que essa consciência do descompasso entre o "papel" e a prática motiva muitas pessoas a pensarem que a Educação Ambiental deveria ser uma disciplina especial ou, pelo menos, que sua criação fosse permitida às escolas: Ora, se sabemos que o Brasil é um país no qual algumas leis "pegam" e outras não, me ocorre que, à luz da maisque disciplinariedade da EA na sua melhor acepção, a lei deveria aconselhar a não-criação de uma disciplina específica de EA, mas é melhor termos pelo menos um espaço garantido de EA na forma de uma disciplina, que não termos nada em absoluto (VELASCO, 2002, p. 4).

Ferreira e Meireles De SÁ (2017) concluem que questão da inserção da EA no currículo escolar tem solução, e é uma já conhecida e esperada desde a promulgação da PNEA em 1999, qual seja, uma reestruturação generalizada, que possibilite e demande o cumprimento daquilo que já se sabe ser fundamental: a) dedicação especial ao processo de formação de educadores ambientais, tanto na formação inicial quanto na formação continuada; b) a ampliação e o fomento do envolvimento de professores, 
direção, funcionários e alunos em espaços de participação e; c) a ampla discussão nacional para definir os desejos com a transversalização e com a interdisciplinaridade na Educação Ambiental, seus limites e possibilidades no contexto educacional brasileiro (LOUREIRO; COSSIO 2007). E alertam:

a simples obrigatoriedade de criação da disciplina específica não garante a solução para o problema atual". Primeiro, porque poderá ser só mais uma lei sem efetividade. Segundo, porque vai na contramão de todos os conceitos, estudos e pesquisas da área da EA. Este PL causa uma revolução com o foco errado. A luta deveria ser outra: por para funcionar aquilo que já é lei.

E propõem:

Assim, tendo em vista a defesa deste interesse social, deveria ser realizada uma ampla consulta on-line, em que fosse possível, de fato, contribuir para a construção do projeto de lei, não apenas concordando ou discordando. Nessa esteira, a realização de audiências públicas seria mais uma excelente maneira de enriquecer a discussão para, só então, chegar-se a um texto final que deveria ser votado (FERREIRA; MEIRELES DE SÁ, 2017).

Neste ponto é importante ressaltar a proposta deste artigo: a criação de comunidades de prática para discutir a legislação do tema de Educação Ambiental e sua inserção de forma transversal, inicialmente nas Escolas de Mariana e Brumadinho. Além da inserção do tema nas escolas, é importante discutir os temas de cidadania via campanhas de conscientização e incentivo a leitura, além é claro de uma comunidade para discutir o tema da governança compartilhada.

No artigo "Reforma da Educação Ambiental: um projeto fadado ao fracasso" Camargo (2017) ressalta que segundo Loureiro (2006) a Educação Ambiental escapa da ideia tradicional de disciplina escolar por ser mais abrangente que qualquer uma destas ao buscar um processo pedagógico participativo, permanente e crítico. Desta forma, para alçar resultados minimamente aceitáveis, ela precisa estar diretamente relacionada com o dia a dia do aluno, as relações dele na sua comunidade, família e natureza são peças chave para se alcançar sucesso nesta temática. De maneira contrária, se não for desta maneira participativa e social a tendência de não funcionar é enorme (MINC, 1997, p. 61).

De acordo com Camargo (2017) uma das características principais da Educação Ambiental está em sua trans e interdisciplinaridade, ou seja, dentro do ambiente escolar e no processo educacional o meio ambiente deve ser abordado de maneira direta ou indireta por todos os seus membros, 
especialmente docentes (BRASIL, 1997), que devem incluir este tema nos projetos conjuntos que são desenvolvidos e abordados ao longo do ano letivo (CAMARGO, 2017).

Camargo (2017) sustenta que talvez o primeiro ponto a ser debatido seja o que vem a ser transversalidade na educação. Este conceito, nada mais é que a importância da junção de vários tipos de conhecimentos que não podem ser trabalhados de maneira separada, ou seja: são inseparáveis (GUERRA; MARÇAL, 2006). O caso da EA é prova disso, não é tornando-a uma disciplina que vai se resolver o problema. O debate está errado, é preciso que se pense sobre as dificuldades de se trabalhar com a transversalidade para avançarmos em tal abordagem pedagógica, ao invés de rebaixar a Educação Ambiental a mais uma disciplina escolar catedrática (CAMARGO, 2017).

No artigo "Um Debate não Circular: por uma Educação Ambiental escolar interdisciplinar" Neto (2017) pergunta qual estratégia a seguir "reafirmar a essência e origem interdisciplinar dessa área (Lei 9795/99), ou optar pela via da disciplinarização (PL 221/2015)?

A primeira opção manterá certa coerência com o cerne da temática ambiental, que é inesgotável por qualquer disciplina científica, mas deverá arcar com certa volatilidade da interdisciplinaridade - a qual é sempre desafiadora em um modelo escolar e acadêmico tão fragmentado e disciplinar quanto o que impera no Brasil de hoje. Já a segunda opção deverá ressaltar o amadurecimento da área da Educação Ambiental e, conforme as argumentações mais correntes, militar pela importância de formações específicas que possam preparar os estudantes para lidar com os desafios ambientais atuais, e que exigiriam docentes com formações distintas para a temática (NETO, 2017).

Não obstante, considerando o histórico da Educação Ambiental e seu momento atual no Brasil, os indícios mais fortes são de que a criação de uma disciplina específica enfraqueceria a discussão ambiental na sociedade. As propostas mais recentes de bases curriculares, como a Base Nacional Comum Curricular, e até mesmo a MP 749/2016, que modifica a estrutura curricular do Ensino Médio, apregoam uma diminuição das disciplinas obrigatórias, e não um aumento. Há uma crítica sendo reiterada na sociedade, inclusive pela grande mídia corporativa, à grande quantidade de disciplinas obrigatórias na escola básica brasileira - esse fator é, inclusive, apontado como um possível contribuinte aos índices de evasão escolar.

Dessa forma, é possível perceber que o debate educacional sobre a questão ambiental no Brasil ainda não atingiu um grau de maturidade e de expressão social para que transformações substanciais sejam impostas às escolas. É preciso que haja mais subsídios a estudos e discussões sobre a temática, em diferentes esferas, para que avanços sejam factíveis considerando a realidade social concreta na qual nos localizamos. Mais exercícios interdisciplinares precisam ser realizados nas escolas, e maior 
diálogo é necessário entre os(as) professores(as) para que a Educação Ambiental escolar seja, primeiramente, fortalecida e melhor entendida, e posteriormente reavaliada.

Pipitone e Nossllala (2010) verificaram que a maioria dos professores das três escolas paulistas possui um conhecimento superficial e até alguns destes, nenhum conhecimento sobre a legislação o que dificulta a sensibilização deles para a inserção desta temática na escola. Quanto às potencialidades citadas pelos professores para a inclusão da Educação Ambiental - EA na escola destaca-se: a possibilidade de efetuarem-se trabalhos de forma interdisciplinar embora isto não esteja ocorrendo na prática (LISBOA; KINDEL, 2012), a integração da EA em vários conteúdos disciplinares, práticas metodológicas voltadas para a discussão, o debate de ideias, a explanação oral, exposição dialogada, boas ações voltadas para o que seria ecologicamente correto, melhorias na qualidade do ambiente escolar e urbano (PIPITONE; NOSSLLALA, 2010).

Evidências sugerem que experiências agradáveis em contato com a natureza podem influenciar positivamente crenças e sentimentos com relação à natureza (COLLADO; CORRALIZA, 2013; NEIMAN; ADES, 2014; RICHARDSON; SHEFFIELD, 2017). Em pesquisa recente, crianças que vivenciaram experiências de lazer em parques abertos tiveram seu sentimento de conexão com a natureza elevado e tenderam a concordar que a visita fez com que elas quisessem cuidar melhor do local (CRAWFORD et al., 2017).

O Centro de Ecologia Aplicada do Instituto Superior de Agronomia da Universidade de Lisboa, Portugal, lançou o programa de Educação Ambiental "tapada da ajuda-uma floresta a descobrir", destinado aos alunos do Ensino Básico e Pré-Escolar. Recorrendo ao espaço agroflorestal privilegiado que é a Tapada da Ajuda, desenvolvem-se atividades que procuram ser complementares às temáticas abordadas num contexto escolar promovendo a sua compreensão do ponto de vista mais prático. Investigam-se os princípios orientadores da ecologia e da conservação da natureza, partindo de atividades lúdicas e de uma abordagem tendencialmente prática e experimental, adequadas ao público em questão.

No Brasil, o Projeto Escola, iniciativa do grupo de voluntários do Greenpeace ao redor do Brasil, busca ampliar a importância de uma nova consciência ambiental para as futuras gerações. Para isso, no ano passado levaram a discussão de temas como aquecimento global, desmatamento na Amazônia, importância da reciclagem e do consumo consciente para dentro das salas de aula e comunidades do país atingindo um total de 500 jovens.

Por outro lado, a falta de tempo de contato e entendimento da natureza não apenas influi no desenvolvimento pessoal e profissional dos brasileiros como também contribui decisivamente para ampliar o gigantesco fosso social e situação ambiental existente no país, promovendo mais exclusão e menos cidadania. 
No que tange aos adultos, a educação não formal, deve ser a partir da cidadania participativa. E aqui nos remetemos ao caráter político da EA enquanto parte da tessitura social e não compartimentalizada instrumentalmente como "fechada" em currículos. O sentido não formal depende do formal que nos orienta ou melhor, se não depende, tem efeitos atrelados ao desenvolvimento da primeira, onde a educação formal provê subsídios para que na educação informal, notadamente, mais próxima ao local, território e às histórias sociais, se estabeleçam as conexões relacionais mais frutíferas de desenvolvimento humano (humano no sentido que já nos referimos).

Morgado e Araújo (2018) destacam que a cidadania participativa, entendida como prática social concernida com o bem comum, representa 0 cerne e horizonte formativo de uma EA comprometida com a transformação concomitante das injustiças sociais e da degradação ecológica. Portanto, pensar EA não é apenas prover teoricamente, mas situar na práxis cotidianas o elemento crítico do bem viver, respeito, bem comum e comprometimento com as gerações futuras, tal como preconizado no artigo 225 da Constituição Federal Brasileira, acerca do cuidado.

As comunidades de Prática são o lugar ideal para discutir as principais finalidades da EA propostas no Programa Nacional de Educação Ambiental (ProNEA) e pelo Tratado de Educação Ambiental para Sociedades Sustentáveis e Responsabilidade Global (Brasília, 2005), além do PLS 221/2015, abrindo assim espaços democráticos e participativos de gestão ambiental comunitária, enquanto instrumentos de aprendizado e emancipação social.

As comunidades de Prática vão, de forma colaborativa, organizar as práticas e políticas de Educação Ambiental, em especial na formação de líderes e educadores. Morgado da Silva e Araújo (2019) destacam que, no contexto da EA, os Fóruns Comunitários constituem uma proposta capaz de contribuir sobremaneira com a construção e o exercício da cidadania. Primeiro porque deve ser um ambiente democrático e participativo onde os conflitos éticos e problemas político-sociais da comunidade são desvelados, analisados e debatidos com a intenção de transformação da realidade.

Esse ambiente é criado a partir da prática de gestão de conhecimento conhecida como "Comunidades de Prática" - CdPs. Contudo, a discussão deve ser mediada por uma prática de Inteligência Organizacional "Análise por experts" a fim de não causar entendimento incompleto da situação ou uma avalanche de informações.

Oliveira e Villardi (2014) explicam que para estimular a formação de CdPs, há de se considerar, conforme alerta Gherardi (2003), que as pessoas, as suas emoções e os desejos influenciam diretamente as interações sociais e a maneira como percebem a si mesmas e os grupos de trabalho. As pessoas, de acordo com a autora, são também motivadas pela busca do conhecimento como um fim em si mesmo.

revista brasileira educação ambiental 
Ao se engajarem em contextos de aprendizagem, as pessoas dialogam, negociam significados baseados em suas experiências profissionais e cotidianas, dinamizam seus processos individuais de reflexão e contribuem com a reflexão dos demais. Assim, a reflexividade, a aprendizagem e a competência social do grupo são coletivamente ampliadas, podendo constituirse em comunidades de prática (CdP) nas organizações (SOUZA-SILVA; DAVEL, 2007).

Três elementos caracterizam uma CdP: domínio, comunidade e prática: (a) Domínio, uma CdP apresenta uma identidade definida por um conjunto compartilhado de interesses, membros comprometidos que detêm uma competência compartilhada, aprendem uns com os outros, se destacam e são valorizados por essa competência coletiva, não são apenas um clube de amigos; (b) Comunidade, participar de uma Cdp envolve participar e discutir de atividades conjuntas, ajuda recíproca e compartilhar informações entre os membros devido a seu interesse no domínio que eles detêm. Para mantê-lo, nas CdPs se constroem relacionamentos que lhes permitem aprender entre si, mesmo que não trabalhem juntos diariamente; (c) Prática é característica de uma CdP porque nela seus membros são praticantes e compartilham experiências, histórias, ferramentas, maneiras de resolver problemas, ou seja, realizam uma prática compartilhada (WENGER, 2006).

A entrada de membros novos na comunidade se faz pelo seu engajamento progressivo, envolvendo-se nas práticas coletivas pela sua 'participação periférica legitimada' (PPL) que perpetua uma CdP pela qual os novatos aprendem e se socializam até serem gradualmente reconhecidos como membros dessa comunidade (GHERARDI et al., 1998).

A adesão ao ambiente informal de interação social e o engajamento coletivo das CdP são importantes para construir, transmitir conhecimento e promover uma aprendizagem em grupo situada (ancorada) na prática (Gherardi et al., 1998).

Sugere-se que seja criada uma Comunidade de Prática para discutir as melhores práticas no ensino e aprendizagem em Educação Ambiental e que seja nomeado um expert no assunto para entregar as propostas ao tomador de decisão.

Obviamente é preciso aqui a união entre a academia onde a Comunidade de Prática estará sediada (produção de conhecimento) e o governo (tomador de decisão em relação as propostas).

Com relação aos mecanismos de participação popular para melhorar a efetividade das políticas públicas ambientais, é importante salientar três grandes desafios: i) criação de uma cultura de compartilhamento de conhecimentos dentro e fora da administração pública para cocriação e implementação de políticas, programas, projetos e atividades; ii) motivar e facilitar uma expressão concisa e organizada na discussão on-line; e iii) uso de ferramentas/sistemas inteligentes e especialistas para transformar a 
informação em conhecimento (contextualização) e, então, em inteligência (aplicação).

O reconhecimento da importância da participação ativa dos cidadãos, do setor privado e de funcionários públicos para a criação de novos conhecimentos, bem como dos sistemas inteligentes e de especialistas para facilitar/orientar a colaboração e analisar este novo conhecimento gerado, deve ser a base de um novo modelo de Educação Ambiental.

Esse novo modelo de Educação Ambiental tem que passar pela avaliação dos três poderes e por isso importante que suas administrações públicas possam entender a transversalidade do tema de Educação Ambiental, o que se insere perfeitamente no Modelo do Novo Serviço Público (DENHARDT; DENHARD, 2003).

\section{Governança compartilhada no modelo do novo serviço público}

Estamos ainda engatinhando na atuação de movimentos sociais e organizações da sociedade civil na luta pela preservação ambiental por meio da participação cidadã e do controle social. Uma das razões para isso é apontada por Almeida (2007), para quem a população brasileira tem forte ideologia pró-estatal, apesar de a maioria da população considerar as instituições privadas mais eficientes e mais confiáveis do que as públicas. Para os mais pobres, o Estado é visto como grande pai protetor. Para as elites, ou o Estado é o responsável por tudo ou é o canal para se garantir alcance dos interesses dos diferentes grupos organizados (ALMEIDA, 2007).

A Governança Compartilhada muda a situação atual de dependência da comunidade com relação ao poder público para uma situação ideal de coresponsabilidade e cidadania no desenvolvimento de ações para a melhoria das condições de vida da comunidade e de maior efetividade das políticas públicas. Modesto (1999) destaca que a governança compartilhada é, sobretudo, uma questão política, relacionada ao grau de desenvolvimento e efetivação da democracia.

Para Paes de Paula (2007), quando analisamos a estrutura do aparelho do Estado pós-Reforma Gerencial, constatamos uma clara concentração do poder no núcleo estratégico. O governo optou pela centralização das decisões e tornou as câmaras setoriais um monopólio das equipes ministeriais. Diniz (2000) corrobora com essa afirmativa e a relaciona com o modelo gerencial, ao afirmar que o desenho institucional trazido pela doutrina da Nova Gestão Pública (NGP) aumentou o isolamento dos decisores, estimulando práticas personalistas e voluntaristas. Por sua vez, Paes de Paula (2007) ressalta que o modelo gerencial é participativo apenas do discurso, mas centralizador no que se refere ao processo decisório, organização das instituições políticas e construção de canais de participação popular.

Pereira (1997), o próprio mentor e coordenador da reforma gerencial, admite que as organizações sociais são excluídas dos poderes de decisão, ao 
afirmar que o papel das chamadas "organizações sociais" para designar a forma de participação da sociedade civil nas políticas públicas, instituída pela Constituição de 1988, se reduz à função e é claramente excluído dos poderes de decisão, reservados ao chamado núcleo estratégico do Estado.

Ao contrário da retórica do modelo gerencial (PEREIRA, 1995), no modelo do Novo Serviço Público (NSP) (DENHARDT; DENHARD, 2003), os cidadãos são chamados de parceiros ou stakeholders (atores interessados), com os quais a esfera pública constrói modelos horizontais de relacionamento e de coordenação.

Para os mentores do NSP, Denhardt e Denhardt (2003), valores como a eficiência e a produtividade não devem ser perdidos, mas devem ser colocados no contexto mais amplo da democracia, da comunidade e do interesse público.

O interesse público é melhor alcançado por servidores públicos e cidadãos comprometidos em fazer contribuições significativas para a sociedade, e não por gestores que atuam como se o dinheiro público fosse seu. Estes gestores deveriam compartilhar a autoridade e reduzir o controle, atuando como líderes transformacionais em vez de chefes ou gerentes.

Nós precisamos de um renovado sentido de comunidade e o governo pode desempenhar um papel importante e fundamental nisso, facilitando e apoiando as conexões entre os cidadãos e as suas comunidades e destas com o governo. Por isso, torna-se o eixo pragmático da reforma administrativa a construção de instituições formais ou informais que induzam os agentes a comportamentos cooperativos.

A mudança do foco na eficiência e na produtividade para o foco na efetividade e na colaboração é a base da mudança do modelo da NGP para o modelo do NSP.

Segundo Andion (2012), as correntes que emergiram nas últimas décadas, como a pluralista e a do NSP, vêm lançar novas bases de compreensão da administração pública e reconfigurar a sua identidade enquanto campo científico, a partir do diálogo com outras disciplinas das ciências sociais, como a ciência política, a sociologia política, a geografia e a antropologia. Fazendo isso, elas trazem à tona novos pressupostos epistemológicos, teóricos e metodológicos para o campo, promovendo o seu enriquecimento. Torna-se possível, assim, pensar outros caminhos metateóricos promissores para além do funcionalismo (Vieira e Caldas, 2006).

Tratando de questões mais práticas, o novo modelo disponibiliza plataformas organizacionais para facilitar o alcance de objetivos públicos, tais como o envolvimento de cidadãos na construção de políticas, fazendo uso de mecanismos de democracia deliberativa e de redes de políticas públicas.

O modelo NSP por si só não resolve o problema de captação e de aplicação do conhecimento coletivo. É preciso um plano integrado de práticas de Gestão do Conhecimento - GC (organizam, transferem e criam 
conhecimento) com práticas de Inteligência Organizacional - IO (analisam, interpretam e aplicam conhecimento).

Não obstante, as pessoas só irão realmente utilizar essas práticas após um processo de humanização no setor público. Tal processo busca transformar servidores públicos alienados e egoístas em pessoas capazes de pensar e de agir como um ser humano em um contexto global, e não simplesmente como pertencente a um seleto grupo de dependentes da máquina pública burocrática.

De Angelis (2013) chama a atenção para o fato de que os líderes devem desenvolver e integrar diferentes competências: Competência Intelectual (IC) - Juízo Crítico e Perspectiva Estratégica; Competência de Gestão (MC) - Comunicação envolvente, gestão de recursos e capacitação; Competência Emocional (CE) - Autoconsciência, Resiliência Emocional, Influência e Motivação; e Competência Espiritual (SC) - Intuição, controle do ego e modos mais elevados de conhecimento. O governo tem que fazer campanhas e oferecer cursos para desenvolver essas competências.

A Universidade de Speyer, na Alemanha, oferece o modelo de um centro de formação cujos programas têm caráter genuinamente multidisciplinarincluindo matérias como história, sociologia, antropologia, ciência política e psicologia.

É nesta mesma linha, a da interdisciplinariedade, que entra a Educação Ambiental, visto poder ser utilizada nesses e em outros ramos do conhecimento, até mesmo na matemática e física.

A prática educativa docente ocorre, por exemplo, na quarta fase do curso de Licenciatura em Educação do Campo da Universidade Federal de Santa Catarina (UFSC), na componente curricular intitulada Fundamentos das Ciências da Natureza e Matemática na Educação do Campo II. Esta componente curricular tem caráter de aprofundar conhecimentos específicos das áreas das Ciências da Natureza e Matemática e foi ministrada por docentes da área de Ensino de Física, Ensino de Matemática e Ensino de Biologia (Borges et. al, 2017).

O processo de interdisciplinariedade vem junto com o processo de colaboração e humanização.

A humanização é parte fundamental tanto do amadurecimento democrático que 0 Brasil está passando neste momento. Esse amadurecimento pode ser acelerado a partir das seguintes iniciativas:

- criação de espaços de participação social com facilitadores e experts que motivam, organizam e analisam o conhecimento gerado;

- melhoria no processo de consulta e consenso;

- equilíbrio na representatividade da diversidade social; 
- solidariedade social (benefícios de ajuda mútua e confiança generalizada);

- forte base de conhecimento comparativo sobre práticas que dão certo;

- liderança do governo, mas também capacidade dos órgãos públicos de se adaptar e absorver novas formas de conhecimento, além da capacidade analítica e interpretativa de atores fora da arena governamental;

- um fluxo de capital social, confiança, entendimento mútuo, conhecimento e saber fazer que permita às pessoas agir, aprender e se adaptar de forma coletiva.

\section{Um modelo de participação popular e mudança cultural para construir um novo paradigma da Educação Ambiental}

A participação e o controle social são os principais elementos de uma governança compartilhada entre Estado e sociedade a fim de melhorar a efetividade das políticas públicas.

A mudança cultural via aprendizagem por colaboração melhora a Educação Ambiental porque incentiva as pessoas a trabalham coletivamente com o sentido e o propósito do bem comum.

De Angelis (2013), em um estudo comparativo entre os governos federais do Brasil e da Alemanha em termos de aplicação das práticas de Gestão do Conhecimento e Inteligência Organizacional, concluiu que os alemães têm uma orientação maior para o futuro em comparação com o brasileiro. A cultura de curto prazo, identificada por Hofstede $(1991,2001)$ e House et al. (2004) é a principal característica dos países latinos.

De Angelis (2016) encontrou que, em oposição à Alemanha, no Brasil, a Inteligência Governamental é mais influenciada pelas crenças e suposições da sociedade do que pelo conhecimento. Isto está relacionado com ao fato de que a cultura alemã, em oposição ao Brasil, ser orientada para o futuro e para o desempenho, obtendo informação de fatos, livros e estatísticas, em vez de ser orientada para as pessoas, obtendo a informação em primeira mão (oral) e tomando a decisão a partir de uma verdade temporária, que depois de analisada com mais cuidado perde sua validade.

Novamente, servimo-nos da abordagem do desenvolvimento como liberdade (SEN, 2000). Essa abordagem enfatiza o papel indispensável da participação popular (livre e inclusiva) na escolha dos objetivos e processos do desenvolvimento de uma nação, bem como na formação dos valores sociais e ambientais. Isso é importante porque, principalmente no mundo globalizado de hoje, o desenvolvimento econômico de uma comunidade pode se chocar com suas tradições culturais e valores, inclusive com suas crenças religiosas e costumes políticos. Em uma situação dessas, o povo deve ter o direito de 
escolher o que fazer com suas tradições culturais, por meio de uma decisão coletiva, livre e racional. Um processo de decisão em que todos os envolvidos tenham a mesma chance de participar, em igualdade de condições, resultará ipso facto em uma decisão legítima do grupo envolvido no processo.

Para Sen (2000, p. 243-244), não se deve subestimar a extensão, a profundidade e o caráter multifacetado das inter-relações culturais que se estabelecem, desde longa data, entre os povos da Terra. De fato, é um mito supor que existam culturas autossuficientes, plenamente autônomas e que, por isso, devam ser preservadas "puras". Não se trata de negar a existência e a importância das culturas nacionais, regionais ou locais, tampouco de negar que dominação cultural possa ter aspectos nocivos às culturas "dominadas". Tratase de reconhecer a importância das referidas influências interculturais, e isso como o resultado de uma capacidade humana de gozar produtos culturais de diferentes povos, lugares e períodos. Consequentemente, as pessoas de diferentes culturas têm a capacidade de compartilhar certos valores e crenças. Segundo Sen, um desses valores é o da liberdade.

O princípio do respeito à liberdade humana, que rege o direito de livre escolha de um povo em relação a suas tradições culturais, tem ao menos duas implicações importantes. Em primeiro lugar, o apelo à tradição não justifica a supressão geral da liberdade de expressão, tampouco a supressão dos direitos políticos e civis da população. Em segundo lugar, a liberdade de participação nas decisões coletivas deve ser sempre assegurada, inclusive com 0 fornecimento das condições básicas para isso - por exemplo, o fornecimento de informações, conhecimentos e educação para o povo. Em termos gerais, na abordagem do desenvolvimento como liberdade, o desenvolvimento exige que o conjunto da população tenha as capacidades e habilidades necessárias para a tomada de decisões coletivas.

Essa frase resume bem duas ideias: a democracia constitui-se num meio e princípio em geral eficaz para forçar o governo a atender o povo; e a democracia exige o exercício da condição de agente (autonomia com responsabilidade) dos indivíduos.

O conhecimento popular tem o potencial de mudar os valores, crenças e suposições dos atores públicos, em especial, quando somado ao aprendizado com outros países e culturas. A mudança cultural via aprendizagem por colaboração melhora a Educação Ambiental porque incentiva as pessoas a trabalham coletivamente com o sentido e o propósito do bem comum.

As relações esboçadas intuitivamente nos parágrafos acima, ganham um caráter formal no modelo de Educação formal e informal e governança compartilhada para criar um novo paradigma para Educação AmbientalEFIGE. A figura 1 ilustra os conceitos e relações do modelo. 


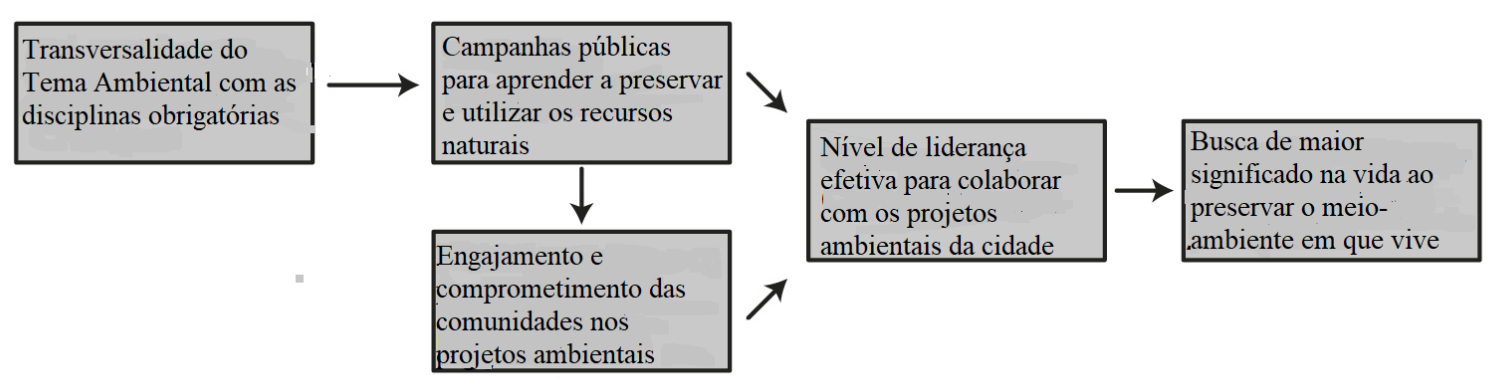

Figura 1: O modelo EFIGE.

Fonte: Elaborado pelos autores.

Para Phillipi Jr e Pelicioni (2005) a fim do propósito do desenvolvimento sustentável, seria fundamental educar a população, para que esta, conscientizada ambientalmente, se engajasse e cobrasse das empresas, governo e sociedade em geral as mudanças pertinentes à própria sustentabilidade humana.

O modelo EFIGE demonstra que uma visão governamental mais holística de mundo, a partir da colaboração interna e externa, gera uma nova consciência em relação à supremacia do interesse público. O modelo é propagador de mudança a partir da responsabilidade social corporativa, da troca de conhecimento e experiência, o que potencialmente é inteligência.

O modelo EFIGE demonstra que uma visão governamental mais holística de mundo, a partir da colaboração interna, o que gera uma nova consciência em relação à supremacia do interesse público. $O$ modelo é propagador de mudança a partir da responsabilidade social corporativa, da troca de conhecimento e experiência, o que potencialmente é sabedoria.

A participação e o controle social de qualidade têm o potencial de abrir espaço dentro do governo para uma governança compartilhada tem força para mudança cultural que leva, sem sombra de dúvida a preservação ambiental. Essa participação e controle social de qualidade, como vimos na revisão de literatura, depende do interesse da sociedade em cobrar do governo o acesso ao conhecimento e experiência, como tem feito os estudantes chilenos. Essa abordagem do desenvolvimento como liberdade, defendida pelo economista e filósofo indiano Amartya Sen, só será atendida nos países latinos a medida que houver respeito a direitos humanos e isso também deve ser uma reivindicação da sociedade brasileira.

\section{Conclusões}

Governar com e para a sociedade, ao invés de governar a sociedade, faz com que o próprio cidadão possa contribuir no desenvolvimento da estratégia, planejamento e gestão dos diversos programas e projetos, melhorando a qualidade do gasto e da ação pública. A participação do cidadão 
e o estabelecimento de parcerias ajudam na transformação da cultura da desconfiança e do curto prazo em uma cultura de colaboração e de longo prazo.

O Estado precisa perceber que a participação e controle social consideram as questões de poder e de interesses divergentes em qualquer projeto público. A partir deste entendimento, o Estado deve se abrir para o conhecimento da sociedade e de outros países para conseguir vencer a crise de confiança e crise econômica, advindas da política de isolamento e manutenção do status quo.

O Estado não tem conhecimentos e recursos suficientes para resolver os problemas contemporâneos e por isso precisa contar com a inteligência proveniente das sociedades doméstica e de outras nações, mormente as mais desenvolvidas.

A Educação Ambiental crítica, neste ponto, permite construção reflexiva sobre Cidadania e o sentido de cidadão em si. No âmbito da educação formal e informal, é passível de desenvolvimento pela liberdade, este pela lógica da liberdade e participação plena como sujeito ativo de transformação social e não um receptor das ações do estado. Ao mesmo tempo, a Educação Ambiental crítica faz frente à educação bancária, fechada e compartimentalizada em disciplinas que não incidem em perspectiva dialógica e transversal. Assim, a ideia da Educação Ambiental, consoante à perspectiva de governança pública que se oriente por um novo paradigma que relacione conhecimento e experiência incentivando participação e controle social.

Conforme discutido neste artigo, a crise é uma oportunidade de rever crenças, valores, suposições e comportamentos em busca de melhores resultados. O lado destrutivo do funcionalismo gerou crises econômicas, sociais, morais e outras formas decorrentes da mãe de todas as crises, que é a crise de percepção. O modelo EFIGE mostra que a troca de conhecimentos entre Estado e sociedade, alimentada pelo aprendizado com outros países, pode mudar o foco da ação governamental para a supremacia do interesse público e a efetividade das políticas públicas, o que automaticamente reduz a corrupção.

\section{Referências}

ANDION, C. Por uma nova interpretação das mudanças de paradigma na administração pública. Cad. EBAPE.BR, v. 10, no 1, artigo 1, Rio de Janeiro, Mar. 2012 p. 15-19.

ANDRADE, S. F., PIRES, M. M. FERRAZ, M. F., Pinheiro, M.S. Índice de Desenvolvimento Como Liberdade: uma proposta teórico-metodológica de análise. Desenvolvimento em Questão, v. 14, n. 34, p. 5-59, 7 jan. 2016. Disponível em: $<$ https://www.revistas.unijui.edu.br/index.php/desenvolvimentoemquestao/articl e/view/4365>. Acesso em 21 de julho de 2020. 
ARAÚJO, M; DOMINGOS, P. Perspectiva teórico-metodológica da Educação Ambiental na escola. Pesquisa em Educação Ambiental, vol.13, n.1, 2018. Disponível em: $<$ http://www.periodicos.rc.biblioteca.unesp.br/index.php/pesquisa/article/view/13 91>. Acesso em 21 de julho de 2020.

BAPTISTA, V. F. A Educação Ambiental para um ambiente equilibrado. Revista Saúde e Ambiente. Disponível em: $<$ http://www.publicacoes.unigranrio.edu.br/index.php/sare/article/download/165 8/828>. Acesso em 21 de julho de 2020.

BERNARDES, M. B. J.; PIETRO, É. C. Educação Ambiental: disciplina versus tema transversal. REMEA - Revista Eletrônica do Mestrado de Educação Ambiental, v. 24, 2010.

BORGES, M. G., FARIA, J. E. S.; BRICK, E. M. Fenômenos como mediadores do processo educativo em Ciências da Natureza e Matemática na Educação do Campo. Revista Brasileira de Educação do Campo, v. 2 n. 3, 2017.

BRASIL. Lei no. 9.795 de 27 de abril de 1999. Dispõe sobre a Política Nacional de Educação Ambiental. Brasília: Diário Oficial da União, Presidência da República, 1999

BRASIL. Ministério da Educação, Secretaria de Educação Fundamental. Parâmetros Curriculares Nacionais (PCN): Introdução aos Parâmetros Curriculares Nacionais. Brasília: MEC/SEF, 1997.

BURSZTYN, M. Meio ambiente e interdisciplinaridade: desafios ao mundo acadêmico. Desenvolvimento e Meio Ambiente, v. 10, p. 67-76, 2004.

CAMARGO, P. L. T. Reforma da Educação Ambiental: um projeto fadado ao fracasso. In: LAMIM-GUEDES, V.; MONTEIRO, R. A. A. Educação Ambiental na Educação Básica: Entre a disciplinarização e a transversalidade da temática socioambiental. 1. ed. São Paulo-SP: Perse, 2017.

CARNEIRO, S. M. M. Fundamentos epistemo-metodológicos da Educação Ambiental. Educar em Revista, Curitiba, n. 27, p. 17- 35, jun. 2006.

DE ANGELIS, C. T. A emergência da reforma do Estado Brasileiro: A governança compartilhada e o modelo do Novo Serviço Público". Revista de Planejamento e Políticas Públicas. IPEA. V. 45, 2015, p.101.

DE ANGELIS, C. T. A Knowledge Management and Organizational Intelligence Model for Public Sector Administrations. International Journal of Public Administration. Issue v. 36, n.11, 2013.

DE ANGELIS, C. T. A Knowledge Management model based on Emotional and Cultural Intelligence: a comparative study between Taiwan and Vietnam. International Scientific Conference on Economic and Social Development. Belgrade, 2018. Disponível em: <http://www.esd-conference.com/pastconferences $>$ Acesso em 21 de julho de 2020. 
DE ANGELIS, C. T. The impact of national culture and knowledge management on governmental intelligence. Journal of Modelling in Management, v. 11, 2016, p. 211.

DE BARROS, G. P. B. Educação Ambiental no Ensino Formal. In: LAMIMGUEDES, V.; MONTEIRO, R. A. A. Educação Ambiental na Educação Básica: Entre a disciplinarização e a transversalidade da temática socioambiental. 1. ed. São Paulo-SP: Perse, 2017

DENHARDT, R.B.; DENHARDT, J.V. The New Public Service: Serving, not Steering. New York: M.E.Sharpe, 2003.

DINIZ, E. Globalização, reformas econômicas e elites empresariais: Brasil anos 1990. São Paulo: Editora FGV, 2000.

DRUCKER, P. The effective executive. HarperCollins Publishers, 1993.

EUSEBIO, L. MENDONZA, A. Educación ambiental: una necesidad en la formación del maestro Museo de Historia Natural. Área Educativa. Universidad Ricardo Palma. The Biologist (Lima). v. 5, n.1, 2007.

FERREIRA, A. C. G. MEIRELES DE SÁ, R. Projeto de Lei do Senado 221/2015: De qual mudança a Educação Ambiental precisa? In: LAMIMGUEDES, V.; MONTEIRO, R. A. A. Educação Ambiental na Educação Básica: Entre a disciplinarização e a transversalidade da temática socioambiental. 1. ed. São Paulo-SP: Perse, 2017

FREIRE. P. Pedagogia do oprimido. Rio de Janeiro: Paz \& Terra, 1994.

GHERARDI, S. Knowing as desiring: mythic knowledge and the knowledge journey in communities of practioners. Journal of workplace learning, v. 15, n. 7-8, 2003.

GUERRA, A. J. T.; MARÇAL, M. S. Geomorfologia Ambiental. Rio de Janeiro: Bertrand Brasil, 2006.

GUERRA, F. Ecopedagogia: contribuições para práticas pedagógicas em Educação Ambiental. Revista de Educação Ambiental. v. 24, n. 1, 2019.

HOFSTEDE, G. Culture's Consequences: Comparing Values, Behaviours, Institutions, and Organisations Across Nations; 2nd ed., Sage Publications: Thousand Oaks, 2001.

HOFSTEDE, G. Cultures and Organisations: Software of the Mind, Harper Collins, London, 1991.

HOUSE, R.J.; HANGES, P.J.; JAVIDAN, M., DORFMAN, P.W; GUPTA, V, Culture, Leadership, and Organisations: The GLOBE Study of 62 Societies, Sage: Palo Alto, 2004.

LAMIM-GUEDES, V.; MONTEIRO, R. A. A. Educação Ambiental na Educação Básica: Entre a disciplinarização e a transversalidade da temática socioambiental. 1. ed. São Paulo-SP: Perse, 2017. 
LISBOA, C. P.; KINDEL, E. A. I. Educação Ambiental da teoria à prática. Porto Alegre: Mediação, 2012.

LOUREIRO, C. F. B. Complexidade e Dialética: Contribuições à praxis política e emancipatória em Educação Ambiental. Educação \& Sociedade, v. 26, n. 93, p.1473-1494. 2006.

LOUREIRO, C. F. B.; COSSíO, M. F. B. Um olhar sobre a Educação Ambiental nas escolas: considerações iniciais sobre os resultados do projeto "O que fazem as escolas que dizem que fazem Educação Ambiental". In: MELLO, S.; TRAJBER, R. (Orgs.) Vamos Cuidar do Brasil: conceitos e práticas em Educação Ambiental. Brasília: MEC/UNESCO, 2007. p. 57-64.

LOUREIRO, C. F.B. Trajetórias e fundamentos da Educação Ambiental. São Paulo: Cortez, 2004.

MACEDO, E. F. Parâmetros curriculares nacionais: a falácia de seus temas transversais. Currículo: políticas e práticas. Campinas: Papirus, 1999.

MINC, C. Ecologia e Cidadania. São Paulo: Moderna. SANTOS, E. C. Educação Ambiental e a tranversalidade na formação de professores: complexidade e desafios do mundo contemporâneo. Revista Geonorte, Edição Especial, v. 3, n. 4, p. 161-170, 2012.

MODESTO, P. Participação popular na administração pública: mecanismos de operacionalização. Jus Navigandi, Teresina, ano, 6, 1999.

MORGADO DA SILVA, M.; ARAÚJO, U. Aprendizagem-serviço e fóruns comunitários: articulações para a construção da cidadania na Educação Ambiental. Revista de Educação Ambiental. Vol. 24, n. 1, 2019.

NETO, D. V. Um Debate não Circular: por uma Educação Ambiental escolar interdisciplinar. In: LAMIM-GUEDES, V.; MONTEIRO, R. A. A. Educação Ambiental na Educação Básica: Entre a disciplinarização e a transversalidade da temática socioambiental. 1. ed. São Paulo-SP: Perse, 2017.

NETO, D. V.; KAWASAKI, C. S. A temática ambiental em documentos curriculares nacionais do ensino médio. Ensaio - Pesquisa em Educação em Ciências, Belo Horizonte, v. 17, n. 2, p. 483-499, 2015.

OLIVEIRA, W. F. Índice de Desenvolvimento Humano e Pegada Ecológica: uma proposta de integração. Anais do: XVI Encontro de Economia da Região Sul, 2013, Curitiba - PR. ANPEC SUL 2013, 2013. Disponível em: $<$ http://www.anpec.org.br/sul/2013/submissao/files 1/i2-

9430aa81204616f26da22cd7797044ec.pdf>. Acesso em 21 de julho de 2020.

PAES DE PAULA, A. P. Cooperação e inovação na gestão pública: o caso da saúde. RAE, São Paulo, v. 47, n. 2, p. 124-125, June 2007.

PEREIRA, L. C. B. A reforma do estado dos anos 90: lógica e mecanismos de controle. Brasília: Mare, 1997. 
PIPITONE, M. A.; NOSSLLLALA, S. K. O Desenvolvimento da Educação Ambiental no Ensino Fundamental: A Participação Dos Programas Oficiais. Revista Eletrônica do Mestrado em Educação Ambiental, 2010. Disponível em: <https://periodicos.furg.br/remea/article/view/3375>. Acesso em 21 de julho de 2020.

SEN, A. Development as freedom. New York: Anchor Books, 2010.

SORRENTINO, M. Desenvolvimento sustentável e participação: algumas reflexões em voz alta. In: LOUREIRO, C. F. B. (Org. et al) Educação Ambiental: repensando o espaço da cidadania. - 5. Ed. - São Paulo: Cortez, 2011, p. 19-25.

SOUZA-SILVA, J. C; DAVEL, E. Da ação à colaboração reflexiva em comunidades de prática. RAE-Revista de Administração de Empresas, v. 47, n. 3, p. 53-65, 2007.

TOYNBEE, A. A humanidade e a Mãe-Terra. Rio de Janeiro: Zahar, 1982. apud ALMEIDA, J.R. Ciências ambientais. 2. ed. Rio de Janeiro: Thex, 2008.

UNESCO/PNUMA. (2016) Carta de Belgrado. Disponível em: $<$ http://www.fzb.rs.gov.br/upload/20130508155641carta de belgrado.pdf>. Acesso em 21 de julho de 2020.

VELASCO, S. L. Perfil da lei de Política Nacional de Educação Ambiental. Revista Eletrônica do Mestrado em Educação Ambiental. Rio Grande, v. 2, jan./mar. 2000. Disponível em: $<$ https://www.remea.furg.br/mea/remea/vol2art3.html>. Acesso em 21 de julho de 2020.

VIEIRA, M.; CALDAS, M. Teoria crítica e pós-modernismo: principais alternativas à hegemonia funcionalista. Revista de Administração de Empresas, São Paulo, v. 46, n. 1, p. 59-70, 2006.

WENGER, E. Communities of practice: a brief introduction, 2006. Disponível em: <http://wengertrayner.com/Intro-to-CoPs/>. Acesso em: 06/12/2010. 